\title{
Impact of direct seeding mulch-based cropping systems on soil nematodes in a long-term experiment in Madagascar
}

\author{
Cécile Villenave ${ }^{(1)}$, Bodovololona Rabary(2), Jean-Luc Chotte ${ }^{(1)}$, Eric Blanchart(1) and Djibril Djigal(3)
}

\begin{abstract}
(1)Unité Mixté Recherche (UMR) 210 ECO\&SOLS SupAgro, 2 place Viala, Bâtiment 12, Montpellier Cedex 1, France. E-mail: cecile.villenave@ird.fr, eric.blanchart@ird.fr, jean-luc.chotte@mpl.ird.fr (2)Fofifa UPR Système de culture et Riziculture durable, BBP230, 110 Antsirabé, Madagascar. E-mail: bodo_rabary@yahoo.fr (3)UMR 210 ECO\&SOLS LEMSAT IRD ISRA, BP 1386 Dakar, Sénégal. E-mail: djibril.djigal@ird.fr
\end{abstract}

\begin{abstract}
The objective of this work was to assess the effects of conventional tillage and of different direct seeding mulch-based cropping systems (DMC) on soil nematofauna characteristics. The long-term field experiment was carried out in the highlands of Madagascar on an andic Dystrustept soil. Soil samples were taken once a year during three successive years (14 to 16 years after installation of the treatments) from a 0-5-cm soil layer of a conventional tillage system and of three kinds of DMC: direct seeding on mulch from rotation soybean-maize residues; direct seeding of maize-maize rotation on living mulch of silverleaf (Desmodium uncinatum); direct seeding of bean (Phaseolus vulgaris)-soybean rotation on living mulch of kikuyu grass (Pennisetum clandestinum). The samples were compared with samples from natural fallows. The soil nematofauna, characterized by the abundance of different trophic groups and indices (MI, maturity index; EI and SI, enrichment and structure indices), allowed the discrimination of the different cropping systems. The different DMC treatments had a more complex soil food web than the tillage treatment: SI and MI were significantly greater in DMC systems. Moreover, DMC with dead mulch had a lower density of free-living nematodes than DMC with living mulch, which suggested a lower microbial activity.
\end{abstract}

Index terms: crop residues, indicator, living mulch, Nematoda, soil functioning.

\section{Impacto do plantio direto com cobertura vegetal nos nematódeos edáficos em experimento de longa duração em Madagascar}

\begin{abstract}
Resumo - O objetivo deste trabalho foi avaliar os efeitos do plantio convencional e de diferentes sistemas de plantio direto com cobertura vegetal (DMC) nas características da nematofauna edáfica. Foi intalado um experimento de longa duração nos platôs centrais de Madagascar em um Inceptisol ândico. $\mathrm{O}$ solo foi amostrado uma vez por ano durante três anos consecutivos (14 a 16 anos após a instalação dos tratamentos) na camada de $0-5 \mathrm{~cm}$ do solo em plantio convencional e em três tipos de DMC: plantio direto sobre cobertura morta de resíduos da rotação soja-milho; plantio direto da sucessão milho-milho sobre cobertura viva de Desmodium uncinatum; plantio direto da rotação feijão-soja sobre cobertura viva de Pennisetum clandestinum. As amostras foram comparadas com amostras oriundas de pousio. A nematofauna do solo, caracterizada pela abundância dos diferentes grupos tróficos e índices (MI, índice de maturidade; EI e SI, índices de enriquecimento e estrutura) permitiu a discriminação dos diferentes sistemas de cultivo. Os sistemas de plantio direto com cobertura vegetal foram caracterizados por uma cadeia trófica mais complexa que a de plantio convencional: SI e MI foram significativamente maiores no plantio direto. O sistema de plantio direto em cobertura morta apresentou menor densidade de nematódeos de vida livre em comparação com os sistemas de plantio direto em cobertura viva, o que sugere uma atividade microbiana mais baixa.
\end{abstract}

Termos para indexação: resíduos culturais, indicador, cobertura viva, Nematoda, funcionamento do solo.

\section{Introduction}

Soil nematofauna is composed of phytoparasitic nematodes, which are well known for the damage they can cause to crops, as well as of free-living nematodes, many of which are microvorous. Due to the abundance and diversity of nematodes in soils as well as to their biological characteristics, these organisms are considered as bioindicators of soil quality (Bongers \& Ferris, 1999; Ritz \& Trudgill, 1999; Villenave et al., 2004).

Moreover, the analysis of soil nematofauna leads to large amounts of data, from the taxa (absolute and relative density of each genera) to the community (the total nematodes density) level. Other nematological 
parameters or indices can be obtained from the whole dataset and are linked to the functions of these organisms in the soil. Among these parameters are the trophic groups (nematodes with same feeding behaviours; Yeates et al., 1993) and the colonizer-persister classes (c-p classes) that separate the nematode taxa along a gradient of demographic traits from opportunist to persister nematodes (Bongers, 1990). Several nematological indices that can be used to explore the soil microbiological functioning (Ferris et al., 2001) have also been developed.

The objective of this work was to assess the effects of conventional tillage and of different direct seeding mulch-based cropping systems on soil nematofauna characteristics.

\section{Materials and Methods}

The study site was located near Antsirabe, in the highlands of Madagascar $\left(19^{\circ} 47^{\prime} \mathrm{S}, 47^{\circ} 06^{\prime} \mathrm{E}\right.$, average temperature of $16^{\circ} \mathrm{C}$ and average annual rainfall of $1,300 \mathrm{~mm}$ ). The cropping systems were set up in 1991 by the Malagasy NGO TAFA with the support of Centre for International Research into Agronomy for Development (Cirad).

The four treatments studied were a conventional tillage system with crop rotation of maize (Zea mays L.) and soybean (Glycine max. L.) (CT m/s) and three kinds of DMC: rotation maize-soybean with residues left at the soil surface $(\mathrm{DMC} \mathrm{m} / \mathrm{s})$; maizemaize using direct seeding over a living mulch of silverleaf (Desmodium uncinatum) (DMC $\mathrm{m} / \mathrm{m}-\mathrm{d}$ ); and rotation bean (Phaseolus vulgaris)-soybean using direct seeding over living mulch of kikuyu grass (Pennisetum clandestinum) (DMC h/s-k). Each system was replicated three times. These cropping systems were compared to the natural fallow (Aristida sp. savanna), which is made up of an herbaceous stratum and some shrubs (especially Mimosa sp. and Helichrysum sp.) called "bozaka". The results presented in this work concern the average fertilization level, which consists of an association of cow manure $\left(2 \mathrm{Mg} \mathrm{ha}^{-1}\right)$ and mineral fertilizer NPK: $30 \mathrm{~kg} \mathrm{~N}, 30 \mathrm{~kg} P$ and $40 \mathrm{~kg} \mathrm{~K} \mathrm{ha}^{-1}$ for soybean and beans, and $70 \mathrm{~kg} \mathrm{~N}, 30 \mathrm{~kg} \mathrm{P}$ and $40 \mathrm{~kg} \mathrm{~K} \mathrm{ha}^{-1}$ for maize (Razafimbelo et al., 2006).

The soil is an andic Dystrustept with $62 \%$ clay, low bulk density of $0.76 \mathrm{~g} \mathrm{~cm}^{-3} ; \mathrm{pH}\left(\mathrm{H}_{2} \mathrm{O}\right), 5.72 ; \mathrm{C}$ content of $45.6 \mathrm{~g} \mathrm{~kg}^{-1}$ soil; CEC of $17.32 \mathrm{cmol}_{\mathrm{c}} \mathrm{kg}^{-1}$ soil in the upper $0-10 \mathrm{~cm}$. The water content at field capacity

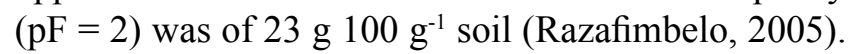
Soil samples were collected at the end of January 2005, 2006 and 2007 during the rainy season. On each of the 12 plots of the agronomic system (three plots for each of the four treatments) and for six plots in the original savanna ("bozaka"), five elementary samplings were carried out on the $0-5 \mathrm{~cm}$ stratum using $250 \mathrm{~cm}^{3}$ cylinders and were then gathered to form a composite sample. The number of six plots in the "bozaka" was chosen because this plot was more heterogeneous than the agricultural fields. Each year, 18 composite samples were analyzed for soil nematofauna. For each composite sample, the water content was measured.

Nematodes were extracted by elutriation (Seinhorst, 1962), counted and fixed in a formalin solution (Villenave et al., 2001). Nematodes were then mounted in mass slides (approximately 250 nematodes per slide) before being identified under a microscope (x300) according to genus or family, and then gathered in trophic groups (Yeates et al., 1993) and in functional guilds, which regroup nematodes of the same trophic group that possess the same characteristics with regard to life history traits (type r or K) (Ferris et al., 2001). The determination of the relative abundance of nematodes in the different functional guilds enables calculating different indices (Maturity Index, MI; Structure Index, SI, and Enrichment Index, EI), whose calculation details are given in Ferris et al. (2001). A two-way analysis of variance was used to analyze the effects of the cropping system and years on the different nematological parameters.

\section{Results and Discussion}

The soil water content was not different between the cropping treatments at the three sampling dates, but was significantly higher in the savanna (Table 1). Samplings were done during the rainy season, and in 2005, 2006, 2007, the water content was near the field capacity. The interaction between year and treatment was linked to the DMC m/m-d for which soil water content (even if it was always lower than that found in "bozaka") was slightly higher than in the other agricultural treatments in 2005 and 2007.

The density of bacterial feeders, fungal feeders and herbivores did not vary significantly between years. Only the carnivorous and omnivorous nematodes showed differences in abundance among the three 


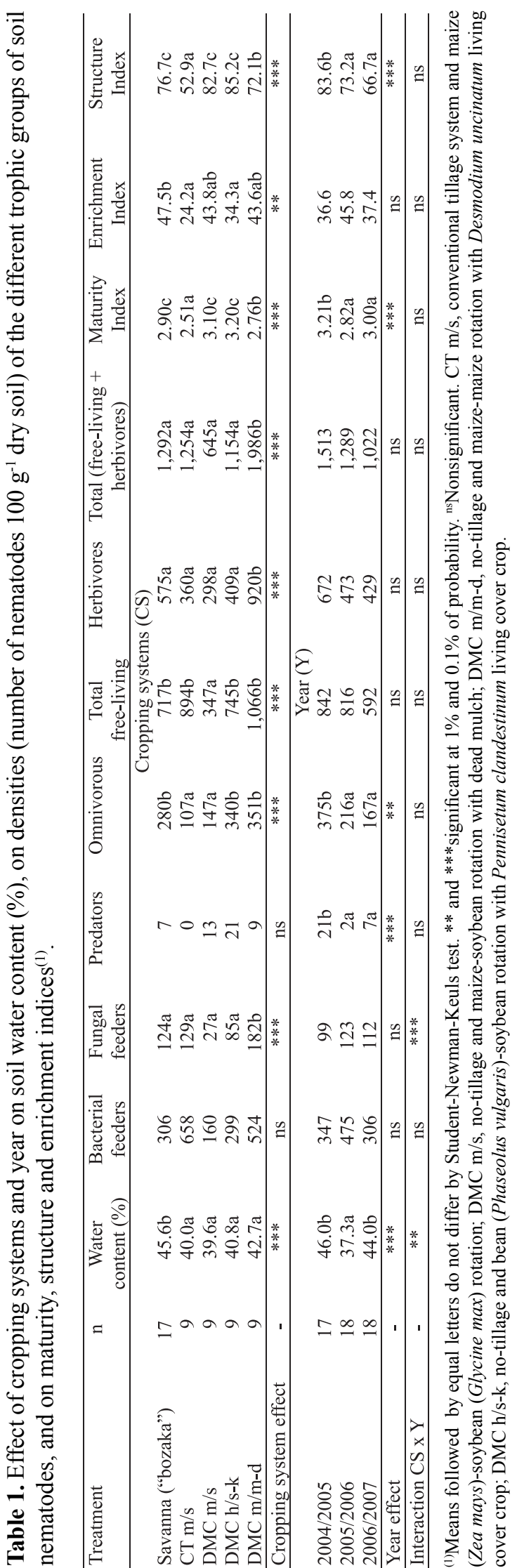

years. They were more abundant in 2005 in comparison to 2006 and 2007 (Table 1). The composition and the structure of the nematofauna were clearly different according to the tillage treatment and the cover crops. The DMC $\mathrm{m} / \mathrm{m}$-d led to a higher density of fungal feeders and herbivores than all the other treatments. The density of omnivorous was also higher in DMC $\mathrm{m} / \mathrm{m}-\mathrm{d}, \mathrm{DMC} \mathrm{h} / \mathrm{s}-\mathrm{k}$ and in the savanna than it was in the conventional tillage treatment $(\mathrm{CT} \mathrm{m} / \mathrm{s})$ and in the DMC with dead mulch (DMC m/s). Densities of predators and bacterial feeders were not significantly different between the five treatments. As in the study of Lenz \& Eisenbeis (2000), in the tillage treatment the nematofauna was dominated by bacterial feeders $(>50 \%)$, whereas in all the other treatments these nematodes had a lower relative abundance.

The savanna showed simultaneously high MI, EI and SI. A high MI $(>2.5)$ as well as a high SI $(>70)$ coupled with a medium EI (30 to 50) characterizes a stable environment where the soil microfood web is complex and well developed (Ferris et al., 2001). As a matter of fact, these indices are calculated by taking into account the proportion of different functional free-living nematode categories (herbivorous excluded): for MI, colonizer-persister categories; for EI, the ratio of the opportunistic nematofauna component (which includes opportunistic bacterial and fungal feeders) on the opportunistic plus the basal nematofauna component; for SI, the ratio of the structure nematofauna component (which includes omnivorous and predators) on the structure plus the basal nematofauna component. Contrary to the savanna, these indices showed the weakest values in the treatment with conventional tillage (CT) as observed by Okada \& Harada (2007) for SI and MI; the soil nematofauna was dominated by microvorous nematodes belonging to the basal nematofauna component, a functional guild resistant to environmental disruption. The carnivorous and omnivorous, usually more fragile, were almost absent $\mathrm{CT} \mathrm{m} / \mathrm{s}$ system. The low value of EI in CT m/s may be linked to a very low nutrient availability in this system. However these indices do not take into account the absolute density of the nematodes for their calculation. For a better interpretation, they must be coupled with this latter parameter. The treatment $\mathrm{DMC} \mathrm{m} / \mathrm{s}$ was characterized by low abundance of free-living nematodes. Contrary to the treatment with conventional tillage, it contained very few 
bacterial-feeding nematodes and especially very few opportunistic bacterial-feeding nematodes $(\mathrm{c}-\mathrm{p}$ value $=1)$. On the other hand, the omnivorous and predators were relatively abundant in comparison to microvorous nematodes. Therefore, DMC $\mathrm{m} / \mathrm{s}$ was a system where the microfood web was long, as shown by the high value of the Structure Index (82.7), but in which the intensity of the processes must be low (Ferris et al., 2001; Villenave et al., 2004). Indeed, the abundance of nematodes is related to the activity of the microbial compartment and the available resources; a low density of free-living nematodes reveals a low microbe, microfauna and mesofauna activity.

The continuous maize cultivation with D. uncinatum as living cover crop (DMC $\mathrm{m} / \mathrm{m}-\mathrm{d}$ ) showed intermediate values of MI, EI and SI, omnivorous density being higher in this system than in CT $\mathrm{m} / \mathrm{s}$ and in DMC m/s. DMC m/m-d presented the highest densities of fungal-feeding nematodes and the highest densities of phytoparasitic nematodes as well, due to the proliferation of Meloidogyne sp. Because these nematodes can lead to considerable damage on certain crops, their presence represents a high phytopathogenic risk for crops. Crop rotation as well as conventional cultivation with tillage are usually known for suppressing plant parasitic nematodes (Fu et al., 2000; Govaerts et al., 2006; Rahman et al., 2007).

The DMC h/s-k system showed clearly the most structured nematofauna among the no-tillage systems (with the highest values for SI and MI); it had high abundance of omnivores and predators and herbivores density lower than that of DMC m/m-d.

Contrary to other studies (Hendrix et al., 1986; Neher, 1999; Nakamoto \& Tsukamoto, 2006), the results of the present work did not show that fungal-feeding nematodes are favoured by simplified soil tillage techniques, with the exception of the D. uncinatum living cover crop system. Moreover, densities of bacterial-feeding nematodes tended to be higher in conventional tillage but the differences were not significant (Lenz \& Eisenbeis, 2000). Omnivorous nematodes were also more abundant in no-tillage systems with a living cover crop (Yeates \& Bongers, 1999).

Complementary analyses are being undertaken to confirm these results in other DMC conditions (other levels of fertilization, other pedoclimatic situations) but also to confirm that the density of the nematodes at a long-scale period (such as in the experiment of this work) is, as suggested, related to the resources available (microbial compartment as well as particular pools of organic matter which may be resources for the microfood web). Linking nematological data to certain physicochemical and biological parameters of the soil available on the site may be useful to discriminate and interpret the differences of composition of nematofauna and to better define the properties of the indicators.

\section{Conclusions}

1. The soil nematofauna, characterized by the abundance of different trophic groups and maturity and its enrichment and structure indices, allows the discrimination of conventional tillage and of different direct seeding mulch-based cropping systems.

2 . The different direct seeding mulch-based cropping systems have a more complex soil food web than the conventional tillage treatment.

3. The lowest density of all free-living nematodes (microvorous, omnivorous and carnivorous) is found in the direct seeding mulch-based cropping system with dead mulch and suggests a lower soil microbial activity in this system.

\section{Acknowledgements}

To Agence de l'Environnement et de la Maîtrise de l'Energie, for funding the project within the framework of the ECO-ECOGER(France); to Agence Universitaire de la Francophonie, for funding the postdoctoral stay of Djibril Djigal in UMR Eco\&sols (France); to all the people who enabled these studies in Madagascar, the members of TAFA NGO and CIRAD as well as IRD in Madagascar.

\section{References}

BONGERS, T. The maturity index: an ecological measure of environmental disturbance based on nematode species composition. Oecologia, v.83, p.14-19, 1990.

BONGERS, T.; FERRIS, H. Nematode community structure as a bioindicator in environmental monitoring. Trends in Ecology and Evolution, v.14, p.224-228, 1999.

FERRIS, H.; BONGERS, T.; DE GOEDE, R.G.M. A framework for soil food web diagnostics: extension of the nematode faunal analysis concept. Applied Soil Ecology, v.18, p.13-29, 2001. 
FU, S.L.; COLEMAN, D.C.; HENDRIX, P.F.; CROSSLEY JR., D.A. Responses of trophic groups of soil nematodes to residue application under conventional tillage and no-till regimes. Soil Biology and Biochemistry, v.32, p.1731-1741, 2000.

GOVAERTS, B.; MEZZALAMA, M.; SAYRE, K.D.; CROSSA, J.; NICOL, J.M.; DECKERS, J. Long-term consequences of tillage, residue management, and crop rotation on maize/wheat root rot and nematode populations in subtropical highlands. Applied Soil Ecology, v.32, p.305-315, 2006.

HENDRIX, P.F.; PARMELEE, R.W.; CROSSLEY, D.A.; COLEMAN, D.C.; ODUM, E.P.; GROFFMAN, P.M. Detritus food webs in conventional and no-tillage agroecosystems. Bioscience, v.36, p. 374-380, 1986.

LENZ, R.; EISENBEIS, G. Short-term effects of different tillage in a sustainable farming system on nematode community structure. Biology and Fertility of Soils, v.31, p.237-244, 2000.

NAKAMOTO, T.; TSUKAMOTO, M. Abundance and activity of soil organisms in fields of maize grown with a white clover living mulch. Agriculture Ecosystems \& Environment, v.115, p.34-42, 2006.

NEHER, D.A. Soil community composition and ecosystem processes - comparing agricultural ecosystems with natural ecosystems. Agroforestry Systems, v.45, p.159-185, 1999.

OKADA, H.; HARADA, H. Effects of tillage and fertilizer on nematode communities in a Japanese soybean field. Applied Soil Ecology, v.35, p.582-598, 2007.

RAHMAN, L.; CHAN, K.Y.; HEENAN, D.P. Impact of tillage, stubble management and crop rotation on nematode populations in a long-term field experiment. Soil and Tillage Research, v.95, p.110-119, 2007.

RAZAFIMBELO, T.M. Stockage et protection du carbone dans un sol ferrallitique sous systèmes en semis direct avec couverture végétale des hautes terres malgaches. 2005. 145p. Thesis (Ph.D.) - Ecole Nationale Supérieure Agronomique de Montpellier, Montpellier.

RAZAFIMBELO, T.M.; ALBRECHT, A.; BASILE, I.; BORSCHNECK, D.; BOURGEON, G.; FELLER, C.; FERRER, H.; MICHELLON, R.; MOUSSA, N.; MULLER, B.; OLIVER, R.; RAZANAMPARANY, C.; SÉGUY, L.; SWARC, M. Effet de différents systèmes de culture à couverture végétale sur le stockage du carbone dans un sol ferrallitique argileux des Hautes Terres de Madagascar. Étude et Gestion des Sols, v.13, p.113-127, 2006.

RITZ, K.; TRUDGILL, D.L. Utility of nematode community analysis as an integrated measure of the functional state of soils: perspectives and challenges. Plant and Soil, v.212, p.1-11, 1999.

SEINHORST, J.W. Modifications of the elutriation method for extracting nematodes from soil. Nematologica, v.8, p.117-128, 1962.

VILLENAVE, C.; BONGERS, T.; EKSCHMITT, K.; DJIGAL, D.; CHOTTE, J.L. Changes in nematode communities following cultivation of soils after fallow periods of different length. Applied Soil Ecology, v.17, p.43-52, 2001.

VILLENAVE, C.; EKSCHMITT, K.; NAZARET, S.; BONGERS, $\mathrm{T}$. Interactions between nematodes and microbial communities in a tropical soil following manipulation of the soil food web. Soil Biology and Biochemistry, v.36, p.2033-2043, 2004.

YEATES, G.W.; BONGERS, T. Nematode diversity in agroecosystems. Agriculture Ecosystems \& Environment, v.74, p.113-135, 1999.

YEATES, G.W.; BONGERS, T.; DE GOEDE, R.G.M.; FRECKMAN, D.W.; GEORGIEVA, S.S. Feeding habits in soil nematode families and genera - an outline for soil ecologists. Journal of Nematology, v.25, p. 315-331, 1993.

$\overline{\text { Received on September 23, } 2008 \text { and accepted on July 2, } 2009}$ 